\title{
PERMAINAN HURUF DAN KATA SEBAGAI UPAYA STIMULASI KEMAMPUAN MEMBACA PERMULAAN PADA ANAK TAMAN KANAK-KANAK
}

\author{
Mirawati $^{1}$, Rini Nugraha ${ }^{2}$ \\ 1-2 Universitas Pendidikan Indonesia \\ Email : mirapaud@gmail.com
}

\begin{abstract}
ABSTRAK
Artikel ini merupakan artikel penelitian terkait penerapan permainan huruf dan kata sebagai upaya stimulasi kemampuan membaca permulaan di TK Laboratorium Percontohan UPI. Tujuan penerapan program ini adalah untuk mengenalkan anak terkait bunyi huruf, bunyi kata dan hubungannya dengan simbol baca melalui permainan. Metode penelitian yang digunakan adalah penelitian tindakan kelas dengan model Kemmis \& McTaggart. Adapun kesimpulan dalam artikel ini merujuk permainaan huruf dan kata sebagai salah satu alternatif pembelajaran untuk menstimulasi kemampuan membaca permulaan pada anak taman kanak-kanak.
\end{abstract}

Kata Kunci: membaca, permulaan, permainan

\begin{abstract}
This article is a research article related to the implementation of letters and words games as an effort to stimulate the ability of eraly reading at the TK UPI Pilot Laboratory. The purpose of implementing this program is to introduce children to the sound of letters, the sound of words and their relationship with symbols read through games. The research method used was classroom action research with the Kemmis \& McTaggart model. The conclusions in this article refer to letters and words games as an alternative learning to stimulate the ability to read early in kindergarten children.
\end{abstract}

Keywords: reading, early, playing

\section{PENDAHULUAN}

Masa usia prasekolah atau masa usia dini merupakan masa yang sangat menentukan bagi perkembangan anak selanjutnya. Pada usia ini sangat penting untuk meletakan dasar-dasar kepribadian anak yang akan menjadi pembentukan kepribadian anak di masa dewasa, oleh karena itu para ahli menyebutnya sebagai usia emas perkembangan (golden age) dimana perkembangan otak pada anak sangat berkembang pesat yaitu sekitar $50 \%$ pada usia 0-4 tahun dan mencapai $80 \%$ pada usia 4-8 tahun sehingga dapat menerima berbagai masukan dari lingkungan sekitarnya dan sangat terbuka dalam menerima berbagai macam pembelajaran dan stimulasi yang diberikan (Direktorat Pendidikan Anak Usia Dini, 2004, hlm. 3).

Sperry, Hubel dan Wisel menjelaskan bahwa perkembangan potensi untuk masing-masing aspek memiliki keterbatasan waktu yang sebagian besar diantaranya terjadi pada masa usia dini (Solehuddin, 1997, hlm. 3). Salah satu potensi yang dimiliki oleh anak adalah kemampuan dalam perkembangan bahasa seperti berbicara, 


\section{Mirawati, Rini Nugraha \\ PERMAINAN HURUF DAN KATA SEBAGAI UPAYA STIMULASI KEMAMPUAN MEMBACA PERMULAAN PADA ANAK TAMAN KANAK-KANAK \\ Early Childhood: Jurnal Pendidikan. Vol. 3 No. 2., November 2019}

mendengarkan atau menyimak, membaca permulaan dan menulis, seperti yang telah diutarakan oleh Hurlock (2000) bahwa pada tahap perkembangan usia prasekolah, anak mulai menguasai berbagai keterampilan fisik, bahasa, dan anak pun mulai memiliki rasa percaya diri untuk mengeksplorasi kemandiriannya.

Salah satu potensi yang dimiiki oeh anak yaitu perkembangan bahasa. Badudu menyatakan bahwa bahasa adalah alat komunikasi atau penghubung antara anggota masyarakat yang terdiri dari individu-individu yang menyatakan pikiran, perasaan, dan keinginannya, selain itu Bromley mendefinisikan bahasa sebagai sistem simbol yang teratur untuk mentransfer berbagai ide maupun informasi yang terdiri dari simbol-simbol visual maupun verbal (Dhieni, 2005). Salah satu keterampilan dalam perkembangan bahasa anak adalah membaca permulaan. Membaca permulaan pada masa kanak-kanak seringkali disebut sebagai kemampuan membaca permulaan atau membaca permulaan. Membaca permulaan adalah kemampuan membaca permulaan anak dalam merangkaikan huruf menjadi kata yang bermakna serta melancarkan teknik membaca permulaan pada anakanak (Muthiani, 2007, hlm. 7).

Kemampuan membaca permulaan pada anak sudah mulai muncul pada usia 4-5 tahun, yaitu kemampuan anak mengenal simbolsimbol, sedangkan untuk usia 5-6 tahun anak sudah mampu menyebutkan simbol-simbol huruf yang dikenal, mengenal suara huruf awal dari nama benda-benda yang ada di sekitarnya, menyebutkan gambar yang memiiliki bunyi atau huruf awal yang sama, memahami hubungan antara bunyi dan bentuk huruf dan membaca permulaan nama sendiri (Permendikbud. No. 137 Tahun 2014). Anak-anak yang memperoleh kemampuan membaca permulaan akan lebih mudah menyerap informasi dan pengetahuan pada masa selanjutnya dalam kehidupan anak itu sendiri. Hal tersebut sejalan dengan pendapat Durkin (Dhieni, 2005, hlm. 5.3) yang menyatakan bahwa:

“....tidak ada efek negatif pada anakanak dari membaca permulaan. Anakanak yang telah dikenalkan membaca permulaan sebelum masuk sekolah dasar pada umumnya lebih maju di sekolah dari anak-anak yang belum pernah memperoleh membaca permulaan".

Potensi kemampuan membaca permulaan ini penting untuk dikembangkan secara maksimal agar anak dapat mencapai tugas perkembangan bahasanya secara optimal. Steinberg (Dhieni, 2005, hlm. 5.3) berpendapat bahwa belajar membaca permulaan akan memenuhi rasa keingintahuan anak, selain itu secara langsung, perkembangan bahasa anak, akan mempengaruhi persepsi anak tentang dirinya dan orang lain. Persepsi anak tersebut akan memberikan pengaruh terhadap pola penyesuaian diri anak secara umum, misalnya anak yang kurang terampil dalam membaca permulaan akan mengalami hambatan ketika anak masuk ke jenjang pendidikan yang lebih tinggi sehingga hal tesebut menyebabkan anak menarik diri dari lingkungan teman-temannya.

Pernyataan di atas memperkuat asumsi bahwa anak perlu mendapatkan kesempatan untuk meningkatkan kemampuan membaca permulaan. Tantangan bagi guru atau pendidik 


\section{Mirawati, Rini Nugraha \\ PERMAINAN HURUF DAN KATA SEBAGAI UPAYA STIMULASI KEMAMPUAN MEMBACA PERMULAAN PADA ANAK TAMAN KANAK-KANAK \\ Early Childhood: Jurnal Pendidikan. Vol. 3 No. 2., November 2019}

adalah menciptakan kondisi pembelajaran yang kondusif bagi proses perkembangan kemampuan membaca permulaananak tersebut. Hal ini senada dengan pernyataan yang diuraikan oleh Hurlock (1980, hlm. 111) yaitu:

"Awal masa kanak-kanak dapat dianggap sebagai saat belajar untuk belajar keterampilan. Apabila anak tidak diberi kesempatan mempelajari keterampilan tertentu, dimana perkembangan keterampilannya sudah memungkinkan untuk melakukan berbagai hal, dan berkembangnya keinginan pada diri anak untuk mandiri, maka anak tidak saja akan kurang memiliki dasar keterampilan yang telah dipelajari oleh teman-teman sebayanya tetapi juga akan kurang memiliki motivasi untuk mempelajari pelbagai keterampilan pada saat diberi kesempatan".

Pada hakikatnya setiap anak memiliki potensi kemampuan membaca permulaan, namun dalam tingkatan yang bervariasi, seperti halnya yang dialami oleh anak di Taman Kanakkanak (TK) Laboratorium Percontohan UPI. Setelah dilakukan observasi, perkembangan kemampuan membaca permulaan anak di TK Laboratorium Percontohan UPI belum terstimulasi secara maksimal. Hal ini ditandai dengan belum terlihatnya keterampilan anak dalam lingkup keaksaraan seperti yang tertuang dalam Permendikbud. No. 137 Tahun 2014. Sebagian besar anak belum mampu menyebutkan simbol-simbol huruf yang dikenal, mengenal suara huruf awal dari nama benda-benda yang ada di sekitarnya, menyebutkan gambar yang memiiliki bunyi atau huruf awal yang sama, memahami hubungan antara bunyi dan bentuk huruf dan membaca permulaan nama sendiri. Berdasarkan hasil observasi awal terkait kemampuan membaca permulaan di atas, anak sebagaian besar berada dalam kategori perlu stimulus. Hasil observasi lainnya yaitu belum terlihatnya kegiatan yang variatif untuk meningkatkan keterampilan anak tersebut di TK Laboratorium Percontohan UPI.

Berbagai upaya yang akan dilakukan untuk pengembangan kemampuan membaca permulaan untuk anak harus menyenangkan dan sesuai dengan tahapan perkembangan dan kebutuhan anak. Salah satu aktivitas yang menyenangkan dan dinyatakan sebagai wahana belajar bagi anak adalah bermain, sebagaimana tercantum dalam kurikulum sebagai suatu kebijakan bahwa bermain merupakan cara yang paling baik untuk mengembangkan kemampuan anak usia dini sesuai dengan kompetensinya. Anak memperoleh dan memproses informasi mengenai hal-hal baru dan berlatih melalui keterampilan yang ada melalui bermain (Direktorat PAUD, 2006, hlm. 5; Solehuddin, 1997, hlm. 45). Adapun solusi yang ditawarkan sebagai upaya peningkatan kemampuan membaca permulaan dalam penelitian ini adalah melalui permainan huruf dan kata. Permainan ini merupakan permainan kreatif (Mayeski, 2002) yang didesain sesuai kebutuhan dan menggunakan bantuan media seperti kartu kata dan lirik lagu sesuai dengan kata yang ingin dikenalkan pada anak.

\section{METODE PENELITIAN}

Metode penelitian yang digunakan adalah metode penelitian tindakan (action research) model Kemmis dan MC Taggart (McNIff \& Whitehead, 2002). Adapun jenis 


\section{Mirawati, Rini Nugraha \\ PERMAINAN HURUF DAN KATA SEBAGAI UPAYA STIMULASI KEMAMPUAN MEMBACA PERMULAAN PADA ANAK TAMAN KANAK-KANAK \\ Early Childhood: Jurnal Pendidikan. Vol. 3 No. 2., November 2019}

penelitian ini menggunakan penelitian tindakan kolaboratif, dimana peneliti terlibat secara langsung dalam proses penelitian sejak awal sampai penelitian tersebut berakhir. Desain penelitian ini dipilih oleh penulis karena karena pada dasarnya penelitian ini bermula dari permasalahan terkait keterampilan membaca permulaan anak di TK Laboratorium Percontohan UPI sehingga diperlukan solusi untuk mengatasi permasalahan tersebut. Partisipan dalam penelitian ini yaitu anak pada kelompok B di TK Tersebut. Kelompok ini dipilih sebagai subjek penelitian karena berada pada level usia berkisar antara lima hingga enam tahun dan pada usia ini diasumsikan telah menguasai pengetahuan yang diperlukan untuk keterampilan membaca permulaan sebagai bagian dari aspek kematangan untuk melanjutkan pada jenjang sekolah dasar

Adapun solusi yang diajukan dalam penelitian ini adalah dengan menerapkan permainan huruf dan kata.

Desain penelitian tindakan model Kemmis dan Mc Taggart (dalam McNIff \& Whitehead, 2002) terdiri dari empat komponen yang meliputi perencanaan, pelaksanaan, pengamatan dan refleksi.

\section{HASIL DAN PEMBAHASAN}

Berdasarkan observasi terkait pelaksanaan permainan huruf dan kata sebagai upaya stimulasi kemampuan membaca permulaan pada anak di taman kanak-kanak antara lain sebagai berikut:

\section{Deskripsi Kemampuan Membaca Permulaan Anak Taman Kanak- kanak}

Membaca adalah sebuah kemampuan mendasar yang harus dimiliki anak agar mampu mendapatkan informasi melalui media tulisan demi keberlangsungan hidup anak lebih lanjut. Sebagian besar kegiatan belajar diisi dengan kegiatan membaca, sehingga, menguasai kemampuan membaca bagi anak akan sangat membantu anak untuk mendapatkan kesempatan dan memahami berbagai pengetahuan lebih awal. Membaca permulaan dapat dikatakan kemampuan awal yang dilewati anak dalam proses menguasai kemampuan membaca secara menyeluruh (Dhieni, 2005).

Membaca permulaan biasa dilakukan atau didapatkan oleh anak usia Taman Kanak-kanak yaitu sekitar 4-6 tahun. yaitu kemampuan anak mengenal simbol-simbol, sedangkan untuk usia 5-6 tahun anak sudah mampu menyebutkan simbol-simbol huruf yang dikenal, mengenal suara huruf awal dari nama benda-benda yang ada di sekitarnya, menyebutkan gambar yang memiiliki bunyi atau huruf awal yang sama, memahami hubungan antara bunyi dan bentuk huruf dan membaca nama sendiri (Permendikbud. No. 137 Tahun 2014). Anak-anak yang memperoleh kemampuan membaca Permulaan akan lebih mudah menyerap informasi dan pengetahuan pada waktuwaktu selanjutnya dalam kehidupan anak itu sendiri. Sebelum pandai membaca, seorang anak harus mengerti terlebih dahulu huruf dan sesudah ia mengenal huruf, barulah ia belajar merangkai kata-kata yang berarti. Pada akhirnya anak memahami satu kalimat secara keseluruhan (Dhieni, 2005).

Gray (Dhieni, 2005) menyebutkan beberapa komponen membaca, termasuk dalam keterampilan membaca permulaan sebagai berikut:

a. Pengenalan Kata-kata (Decoding). Pengenalan kata ini ditekankan pada 
pengenalan persamaan antara apa yang diucapkan dan apa yang ditulis sebagai symbol.

b. Pengertian. Selain mengenali simbol dan dapat mengucapkan, dalam membaca yang terpenting adalah mengerti apa yang dibaca atau memahamai makna bacaan.

c. Reaksi. Reaksi ini merupakan suatu tahapan dimana anak diharapkan menunjukkan reaksi terhadap hal yang dibaca.

d. Penggabungan. Asimilasi ide-ide yang diharapkan dari mereka dengan pengalaman pembaca di masa lalu.

Steinberg (Dhieni, 2005, hlm. 53) berpendapat mengenai manfaat mengajarkan anak membaca permulaan, antara lain sebagai berikut:

a. Membaca permulaan akan memenuhi rasa keingintahuan anak.

b. Membaca permulaan dapat berkontribusi terhadap situasi akrab dan informal di dalam rumah atau di sekolah (Taman Kanak-kanak), karena anak akan memiliki kemampuan untuk membaca situasi.

c. Anak-anak dapat memiliki kemampuan membaca yang lebih baik pada jenjang lebih lanjut.

d. Anak juga dapat membentuk pengetahuannya terhadap bahasa secara lisan dan semua pengalaman tulisan ketika belajar membaca. Melalui pengamatan yang menyenangkan terhadap tulisan dan bahasa yang mereka dengarkan pada saat dibacakan cerita, kemampuan berfikir dan berkomunikasinya akan berjalan sejalan dengan pertumbuhannya.

Berdasarkan uraian di atas dapat disimpulkan bahwa kemampuan membaca permulaan hakikatnya dapat dikenalkan pada anak taman kanakkanak. Pada hakikatnya setiap anak memiliki potensi kemampuan membaca permulaan, namun dalam tingkatan yang bervariasi, seperti halnya yang dialami oleh anak di Taman Kanakkanak (TK) Laboratorium Percontohan UPI. Setelah dilakukan observasi, perkembangan kemampuan membaca permulaan anak di TK Laboratorium Percontohan UPI belum terstimulasi secara maksimal. Hal ini ditandai dengan belum terlihatnya keterampilan anak dalam lingkup keaksaraan seperti yang tertuang dalam Permendikbud. No. 137 Tahun 2014. Sebagian besar anak belum mampu menyebutkan simbol-simbol huruf yang dikenal, mengenal suara huruf awal dari nama benda-benda yang ada di sekitarnya, menyebutkan gambar yang memiiliki bunyi atau huruf awal yang sama, memahami hubungan antara bunyi dan bentuk huruf dan membaca permulaan nama sendiri.

\section{Penerapan Permainan Huruf dan Kata sebagai Upaya Stimulasi Kemampuan Membaca Permu- laan bagi anak TK \\ Permainan huruf dan kata yang} diterapkan dalam penelitian ini yaitu permainan huruf dan kata melalui aktivitas bernyanyi dan bermain kartu kata. Penjelasannya sebagai berikut:

\section{a. Permainan huruf dan Kata melalui aktivitas bernyanyi}

Tantranurandi (2008, hlm. 31) mengungkapkan bahwa bernyanyi ialah suatu ktivitas yang mengucapkan suatu kata atau kalimat yang dinyanyikan. Sejalan dengan pendapat tersebut, Kojeh (2007) mengemukakan bahwa bernyanyi adalah suatu kegiatan yang mempunyai empat faktor pendorong 


\section{Mirawati, Rini Nugraha \\ PERMAINAN HURUF DAN KATA SEBAGAI UPAYA STIMULASI KEMAMPUAN MEMBACA PERMULAAN PADA ANAK TAMAN KANAK-KANAK \\ Early Childhood: Jurnal Pendidikan. Vol. 3 No. 2., November 2019}

agar lebih efektif dalam penggunaannya, yaitu: konsentrasi, jiwa yang tenang, pengulangan dan motivasi diri. Anwar (2008, hlm. 13) berpendapat bahwa bernyanyi ialah suatu kegiatan mengajar yang menggunakan lirik-lirik yang dilakukan. Mendukung pendapat Anwar, Satibi (2005) pun berpendapat bahwa bernyanyi ialah suatu aktivitas yang dapat merangsang pembelajaran secara nyata yang mampu membuat anak senang dan gembira melalui ungkapan kata dan nada.

Berdasarkan pernyataan di atas, permainan huruf dan kata melalui aktivitas bernyanyi ini merupakan aktivitas pembelajaran yang menekankan pada kata-kata yang dilagukan dengan suasana menyenangkan sehingga anak tidak merasa jenuh. Mahmud \& Fat (1999, hlm. 2-3) berpendapat bahwa aktivitas bernyanyi harus sesuai dengan tahap perkembangan anak, untuk itu Mahmud \& Fat (1999) menjelaskan lebih lanjut bahwa:

1) Isi lagu harus sesuai dengan taraf perkembangan anak. Pendidik atau orang dewasa ketika akan menerapkan aktivitas bernyanyi ini hendaknya memperhatikan isi lagu yang akan diberikan pada anak. Isi lagu tersebut haruslah sesuai dengan taraf perkembangan anak dan seyogyanya bukanlah lagu yang memiliki isi untuk taraf orang dewasa seperti lagu yang mengandung isi kekerasan, konflik percintaan, dan lain sebagainya.

2) Bahasa yang digunakan sederhana dan dapat dimengerti anak. Bahasa yang terdapat dalam lagu yang akan diberikan pada anaak hendaknya sederhana dan dimengerti oleh anak, sehingga anak tidak akan mengalami hambatan dalam penyerapan informasi atau kata-kata yang terdapat dalam lagu tersebut.

3) Luas wilayah nada sepadan dengan kesanggupan alat suara dan pengucapan anak. Pendidik hendaknya memperhatikan luas nada dalam lagu. Luas wilayah nada harus sesuai dengan kesanggupan alat suara dan pengucapan anak, misalnya tidak memiliki not nada yang terlalu tinggi, tidak memiliki tempo yang terlalu cepat, dan lain sebagainya.

4) Tema lagu diupayakan mengacu pada aspek perkembangan anak. Penerapan permainan melalui kegiatan bernyanyi di Taman Kanak-kanak hendaknya diupayakan mengacu pada pemberian lagu yang sesuai dengan perkembangan anak.

Berdasarkan uraian di atas, beryanyi dapat memberikan suasana pembelajaran yang menyenangkan, melalui penerapan permainan huruf dan kata dengan aktivitas bernyanyi ini anak menjadi senang dan lebih mudah dalam memahami materi ajar yang disampaikan. Hal ini sesuai dengan pernyataan Solehuddin (1997) bahwa bernyanyi dapat mengembangkan minat dan apresiasi musik, bahkan juga mengembangkan kemampuan bahasa anak secara lebih luas, meningkatkan kedekatan hubungan antara pendidik dengan anak, menyejukan, memberi ketenangan, menumbuhkan rasa humor, merangsang kemampuan berfikir, mengembangkan rasa harga diri anak serta dapat digunakan untuk pelajaran. Senada dengan pendapat tersebut, bernyanyi menurut Campbell (2003, hlm. 10) dapat memberikan kebahagian pada anak-anak terutama ketika mereka 
bergoyang, menari, bertepuk, dan bernyanyi bersama seseorang yang mereka percayai dan cintai. Selain memberikan kesenangan pada anak, bernyanyi ini diasumsikan sebagai salah satu pendekatan yang cukup tepat jika digunakan sebagai sarana dalam menyajikan proses pembelajaran membaca Permulaan bagi anak TK.

Adapun contoh nyanyian yang akan digunakan dalam permainan huruf dan angka untuk meningkatkan keterampilan membaca permulaan ini antara lain sebagai berikut:

Tabel 1. Lirik lagu dan Tahapan Permainan Huruf dan Kata melalui Kegiatan Bernyanyi

\begin{tabular}{|c|c|c|}
\hline $\begin{array}{l}\text { Nama } \\
\text { Lagu }\end{array}$ & Lirik Lagu & $\begin{array}{c}\text { Aktivitas } \\
\text { Permainan }\end{array}$ \\
\hline $\begin{array}{c}\text { Mengenal } \\
\text { Huruf } \\
\text { Vokal } \\
\\
\text { Karya: } \\
\text { Mirawati }\end{array}$ & $\begin{array}{c}\text { Ayo kawan } \\
\text { mari kita } \\
\text { belajar } \\
\text { Belajar } \\
\text { bersama } \\
\text { mengenal } \\
\text { huruf vokal } \\
\text { Ayo kawan } \\
\text { mari kita } \\
\text { belajar } \\
\text { Belajar } \\
\text { bersama } \\
\text { mengenal } \\
\text { huruf vokal } \\
\\
\text { A a a a } \\
\text { (ayam, } \\
\text { angsa, dll) } \\
\text { I i i i (ikan, } \\
\text { itik, iguana, } \\
\text { dll) } \\
\text { U u u u } \\
\text { (ular, unta, } \\
\text { dl) } \\
\text { E e e (elang, } \\
\text { dll) } \\
\text { O o }\end{array}$ & $\begin{array}{c}\text { Guru } \\
\text { mengenalkan } \\
\text { lagu pada } \\
\text { anak. Ketika } \\
\text { sampai pada } \\
\text { lirik } \\
\text { pengenalan } \\
\text { masing- } \\
\text { masing huruf } \\
\text { vokal guru } \\
\text { meminta anak } \\
\text { untuk } \\
\text { menyebutkan } \\
\text { nama-nama } \\
\text { binatang atau } \\
\text { benda lainnya } \\
\text { yang memiliki } \\
\text { huruf awalan } \\
\text { sesuai dengan } \\
\text { huruf vokal } \\
\text { yang } \\
\text { disebutkan. }\end{array}$ \\
\hline
\end{tabular}

\begin{tabular}{|c|c|c|}
\hline & $\begin{array}{c}\text { (orangutan, } \\
\text { dll) } \\
\text { Itu huruf } \\
\text { vokal } \\
\text { A I U dan E } \\
\text { O } \\
\text { Itu huruf } \\
\text { vokal }\end{array}$ & \\
\hline $\begin{array}{c}\text { Mengenal } \\
\text { Suku } \\
\text { Kata } \\
\\
\text { Karya: } \\
\text { Mirawati } \\
\text { \& Rini } \\
\text { Nugraha }\end{array}$ & $\begin{array}{c}\text { Ayo kawan } \\
\text { mari kita } \\
\text { belajar } \\
\text { Belajar } \\
\text { bersama } \\
\text { mengenal } \\
\text { suku kata } \\
\\
\text { Ayo kawan } \\
\text { mari kita } \\
\text { belajar } \\
\text { Belajar } \\
\text { bersama } \\
\text { mengenal } \\
\text { suku kata } \\
\text { Ba ba ba ba } \\
\text { (batu, baju, } \\
\text { dll) } \\
\text { Bi bi bi bi } \\
\text { (biru, bika, } \\
\text { dll) } \\
\text { Bu bu bu bu } \\
\text { (buku, busa, } \\
\text { dll) } \\
\text { Be be be be } \\
\text { (bebek, } \\
\text { becak, dll) } \\
\text { Bo bo bo bo } \\
\text { (bola, bobo, } \\
\text { dll) } \\
\text { Itu suku } \\
\text { kata } \\
\text { Ba, Bi, Bu } \\
\text { dan Be, Bo } \\
\text { Itu suku } \\
\text { kata }\end{array}$ & $\begin{array}{c}\text { Guru } \\
\text { mengenalkan } \\
\text { lagu pada } \\
\text { anak. Ketika } \\
\text { sampai pada } \\
\text { lirik } \\
\text { pengenalan } \\
\text { masing- } \\
\text { masing huruf } \\
\text { suku kata guru } \\
\text { meminta anak } \\
\text { untuk } \\
\text { menyebutkan } \\
\text { nama-nama } \\
\text { benda, } \\
\text { binatang, } \\
\text { tanaman atau } \\
\text { kata lainnya } \\
\text { yang memiliki } \\
\text { suku kata } \\
\text { dengan huruf } \\
\text { konsonan b, c, } \\
\text { d, dan } \\
\text { seterusnya. }\end{array}$ \\
\hline
\end{tabular}




\section{b. Permainan huruf dan Kata melalui Kegiatan Bermain Kartu Kata}

Kartu dalam kamus besar bahasa indonesia (KBBI) adalah kertas tebal yang bebentuk persegi panjang, sedangkan istilah kata menurut KBBI adalah tanda aksara atau tata tulis yang melambangkan bunyi bahasa dan aksara pada suatu objek. Berdasarkan pengertian tersebut dapat disimpulkan bahwa kartu kata adalah jenis kertas yang brukuran tebal dan berbentuk persegi panjang yang ditulisi atau ditandai dengan kata tertentu tertentu. Adapun kartu kata yang akan digunakan dalam permainan huruf dan kata pada penelitian ini adalah kartu kata yang disertai dengan gambar benda/binatang atau objek lainnya yang bermakna untuk anak.

Huruf yang digunakan dalam pelajaran membaca permulaan terdiri atas 26 huruf yang terbagi atas 5 huruf vokal dan 21 huruf konsonan, namun dalam kartu kata ini abjad tersebut telah tersusun berdasarkan kata tertentu disertai dengan gambar yang sesuai dengan kata tersebut. Langkah pelaksanaan permainan huruf dan kata melalui bermain kartu kata ini antara lain sebagai berikut:

1) Anak diminta mengambil kartu kata yang telah disediakan guru secara acak sesuai dengan instruksi guru.

2) Anak diminta untuk menyebutkan kata yang tertera dalam kartu (dalam hal ini anak dibantu dengan bantuan gambar).

3) Anak diminta kembali mengambil kartu yang lain dan menyebutkan kata yang ada. Kegiatan ini dapat di ulang terus menerus, hingga anak mengenal tulisan dalam kartu.

4) Pada kegiatan selanjutnya disiapkan dua jenis kartu, yang satu kartu yang hanya ada gambarnya saja, dan satunya lagi kartu yang hanya ada tulisan.

5) Anak diminta untuk mengambil kartu yang hanya memiliki gambar, kemudian diminta untuk mencari kartu pasangan gambar tersebut (kartu tulisan).

Contoh desain kartu kata yang dibuat sesuai dengan kebutuhan permainan huruf dan kata di TK Laboratoriun Percontohan UPI antara lain sebagai berikut:

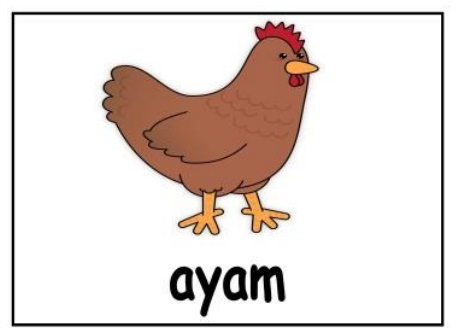

Gambar 1. Kartu Kata "Ayam"

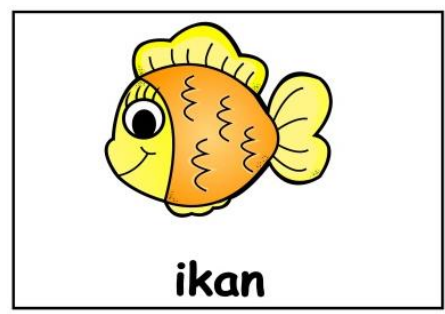

Gambar 2. Kartu Kata "Ikan"

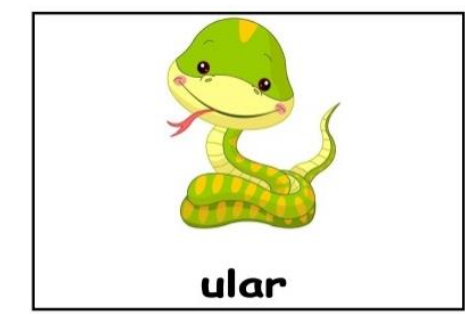

Gambar 3. Kartu Kata "Ular"

\section{Prinsip Pengenalan Membaca Permulaan di TK}

Penerapan permainan huruf dan kata yang telah dilaksanakan di TK Lab. 


\section{Mirawati, Rini Nugraha \\ PERMAINAN HURUF DAN KATA SEBAGAI UPAYA STIMULASI KEMAMPUAN MEMBACA PERMULAAN PADA ANAK TAMAN KANAK-KANAK \\ Early Childhood: Jurnal Pendidikan. Vol. 3 No. 2., November 2019}

Percontohan UPI Sebagai upaya stimulasi kemampuan membaca permulaan hakikatnya telah disesuaikan dengan prinsip pengenalan membaca permulaan bagi anak di jenjang taman kanak-kanak, antara lain (Muthiani, 2007, hlm. 7):

a. Materi bacaan harus terdiri dari kata-kata, frasa, dan kalimat yang disertai dengan gambar konkret bagi anak.

b. Membaca terutama harus didasarkan pada kemampuan anak memahami bahasa lisan bukan hanya pada kemampuan berbicara.

c. Membaca bukan mengajarkan aspek-aspek bahasa atau konsepkonsep (tata bahasa).

d. Membaca tidak harus bergantung pada pengajaran menulis.

e. Mengenalkan membaca harus menyenangkan bagi anak.

Berdasarkan lima prinsip pengajaran kemampuan membaca Permulaan yang dikemukakan di atas, maka pembelajaran membaca pada anak Taman Kanak-kanak berbeda dengan pembelajaran membaca pada jenjang pendidikan lainnya. Pada anak Taman Kanak-kanak belum di tekankan pada aspek tata bahasa yang kompleks, namun lebih kepada kegiatan pembelajaran yang menyenangkan.

\section{Kemampuan Membaca Permu- laan Anak setelah penerapan Permainan Huruf dan Kata}

Kemampuan membaca anak di TK Laboratorium Percontohan UPI setelah penerapan permainan huruf dang angka mengamai peningkatan yang cukup baik. Hal tersebut ditandai dengan munculnya kemampuan anak dalam menyebutkan simbol-simbol huruf yang dikenal seperti huruf a pada kata ayam, huruf I pada kata ikan daln lain sebagainya. Anak juga mampu mengenal suara huruf awal dari nama benda-benda yang ada di sekitarnya, menyebutkan gambar yang memiiliki bunyi atau huruf awal yang sama, memahami hubungan antara bunyi dan bentuk huruf dan membaca permulaan nama sendiri.

\section{SIMPULAN}

Berdasarkan seluruh uraian di atas, dapat disimpulkan bahwa permainan huruf dan kata merupakan salah satu alternative pembelajaran sebagai upaya untuk menstimulasi kemampuan membaca awal bagi anak di taman kanak-kanak khususnya di TK Laboratorium Percontohan UPI.

DAFTAR PUSTAKA

Anwar, M. (2008). Tak Surut Ciptakan Suasana Menyenangkan. [online]. Tersedia: koranpendidikan.com/versi_cet ak-949.html. Diakses pada : 16 Oktober 2018.

Campbell, D. (2003). Mengembangkan Kreativitas. Yogyakarta: Kanisius.

Dhieni, N., dkk. (2005). Metode Pengembangan Bahasa. Jakarta: Universitas Terbuka.

Direktorat Jenderal Pendidikan Luar Sekolah Direktorat Pendidikan Anak Usia. (2004). Modul Sosialisasi PADU, Konsep Dasar Pendidikan Anak Usia Dini. Jakarta: Depdiknas.

Direktorat Jenderal Pendidikan Luar Sekolah Direktorat Pendidikan 


\section{Mirawati, Rini Nugraha}

PERMAINAN HURUF DAN KATA SEBAGAI UPAYA STIMULASI KEMAMPUAN

MEMBACA PERMULAAN PADA ANAK TAMAN KANAK-KANAK

Early Childhood: Jurnal Pendidikan. Vol. 3 No. 2., November 2019

Anak Usia. (2006). Konsep

Dasar Pendidikan Anak Usia

Dini. Jakarta: Depdiknas.

Hurlock, E. B. (1980). Perkembangan Anak. Jakarta : Erlangga.

Hurlock, E. B. (2000). Psikologi Perkembangan: Suatu Pendekatan. Sepanjang Rentang Kehidupan. Jakata: Erlangga.

Kemmis, S. \& Mctaggart, R. (2005). Participatory action research communicative action and the public sphere, Handbook of qualitative research. London: SAGE Publications.

Kojeh. S. A. (2007). Artikel Pendidikan. [online]. Tersedia: http://msaifunsalakim.blogspot. com/2007/2009/artikelpendidikan-m-saifunsalakin_4728.html. Diakses pada: 16 Oktober 2018.

Kurniati, E. (2008). Bahan ajar diklat tenaga pendidik paud nonformal tingkat dasar: Bermain. Bandung: Direktorat PTK PNF Dirjen PMPTK Departemen Pendidikan Nasional dengan Universitas Pendidikan Indonesia.

Mahmud, AT. Dan Fat. 1994. Musik dan Anak . Jakarta: Proyek Pendidikan Tenaga Akademik Depdikbud.

Mayeski, M. (2002).creative activities for young children, 7th edition. United States: Delmar.

McNiff. J \&Whitehead. J (2002). Action research: Principles and practice, second edition. USA: RoutledgeFalmer.

Muthiani. (2007). Agar Anak Suka Membaca. Yogyakarta : Media Insani.

Peraturan Menteri Pendidikan dan Kebudayaan Nomor 137 Tahun 2014. Jakarta: Depdiknas.

Satibi. (2005). Metode Pengembangan Bahasa Moral dan Nilai-nilai Agama. Jakarta: Universitas Terbuka.

Solehuddin, M.(1997). Konsep Dasar Pendidikan Prasekolah. Bandung: FIP IKIP Bandung

Sugianto, M. (1995). Bermain, Mainan dan Permainan. Jakarta: Depdikbud Dirjen Dikti

Tantranurandi. dkk. (2008). Metode Bernyanyi [online]. Tersedia: http://blog.tp.ac.id/pdf/tag/meto de-menyanyi-di-tk-menurutparaahli.pdf. Diakses pada: 16 Oktober 2018. 